\title{
Shifting Security Paradigm in Contemporary Era: Role of Law Enforcement Agencies
}

\author{
Sudip Pandit \\ Inspector of APF, Nepal \\ Assistant to Academic Program Coordinator \\ APF Command and Staff College, Kathmandu, Nepal \\ Email: sudippandit99@gmail.com
}

\begin{abstract}
s
In setting of today's security challenges, striving for sound policing of military character through paramilitary, auxiliary and armed police forces has usurped. The law enforcement agencies are engaged to curb the security threats at realm of dynamic security challenges. The changing perspectives of security scenario along with modern security challenges like terrorism, out and in migration, armed activities and actions of non-state actors are very common to states. The security challenges due to the increase in terrorism, extremism, armed conflict, insurgency, civil war, cyber threats, and non-state actor's activities, are some of the looming security concerns affecting effectiveness and efficacy of the law enforcement agencies. This research is conducted by applying descriptive research method and secondary sources to identify the perspectives of modern-day security situation and role of law enforcement agencies to combat these challenges. This paper highlights the contemporary security challenges contextualized at the global realm to offer possible future strategies in general for the security agencies within and outside the country.
\end{abstract}

Key Words: Security paradigm, contemporary era, law of enforcement agencies, modern security challenges, paramilitary

\section{Introduction}

"Security is like virginity: you're either a virgin or you're not. You either have security or you don't" (President Lennart Meri; in Kaljurand, 2012).

This quote from the former Estonian President Lennart Meri rightly defines the essence of security, even if no state can claim to possess security in absolute terms, because security in absolute terms does not exist, no state can be satisfied with being only a little bit secure. Hence every state, whether big or small, needs a strategy to provide its nation with security (Kaljurand, 2012).

Security is a multi-dimensional concept that relates to the protection from harm or 'freedom from threat'. Thus, questions arise as to what security actually means? Who needs security? Who are the security providers? So, security topics come to their where security in the sense of protection to state and people's lives. The state is the security provider from inside and outside threats. Without security a country remains exposed to and vulnerable to many threats, thus security of lives and property is a dire need for any thriving country (Iregbenu \& Uzonwanne, 2015). Security in its comprehensive sense is the degree of resistance and protection from harm or danger (Baral \& Shah, 2018, p.1). The agencies that work for the protection of the state and people are called law enforcement agencies. The law enforcement agencies identify the probable threats to the life and property of the people of which the state has the responsibility to protect and secure. It is the security agency which helps to ensure that people obey particular laws and rules in a defined territory, state or country. In fact, the security agencies enforce the legislation in any state. Threats are challenges to the state. The Westphalia notion of security which advocated the core idea of security was concentrated on security of state, popularly called the conventional notion of security. Multiple threats that defy military solutions have driven scholars to challenge conventional notions of security, and to redefine the concept so that it encompasses not only freedom from physical violence, but also material well-being of individuals and the environmental health of the planetary system (Dokubo, 2010, p.139; Ngwube, 2013, p. 263). A responsible state should enhance the personal safety of people who reside within and outside the defined territory.

In this contemporary era, security studies scholarly research and academic writings have mainly started focusing on armed conflicts and problems associated inside the society of the state like ethnic conflict, regionalism, secessionist movements, armed struggle, civil war and insurgency. In 1996, BoutrosBoutros Ghali, the Secretary General of the United Nations (UN), observed that globalization was creating a world that has become increasingly interconnected, and a positive force for, inter alia, 
decolonization, good government, development, human rights, and the environment (Manwaring, 2011, p.58). The Secretary General understood, too, that fragmentation was acting as a negative force leading people everywhere to seek refuge in smaller groups, characterized by isolationism, separatism, fanaticism, and the proliferation of intrastate conflict (Manwaring, 2011, p. 58). Therefore, the living standard of the people has been constantly changing due to the innovations of science and technology. Also, globalization of trade and economics has given rise to technological advancements and interconnection among states and peoples.

The contemporary security challenges identify the questions relating to the security of state power from the micro dynamics. The citizens of the nation are considered as state power. As a guardian of the state, the law enforcement agencies have the responsibility to protect the people from harm and maintain peace and stability within the state. One of the primary purposes of any law enforcement agency is the security of the nation and its people. Rather, the contemporary security challenges for the law enforcement agencies are to identify the major inadequacies that have made the society vulnerable to social crimes, considering the threats to the internal security of states. This article highlights the major challenges in the contemporary era and looks for questions regarding what the modern security challenges are. What are the international law enforcement agencies trends to defeat the contemporary security challenges? What are the mechanisms and initiatives developed by state to tackle the security challenges? This article reviews various studies related to contemporary security issues and the role of law enforcement agencies in the security sector. It provides an opportunity for law enforcement agencies that have been facing persistent security challenges to mitigate the internal security threat and study some ideas that are being currently practiced by some of the law enforcement agencies regarding internal security matters, and curb the threats to society and people.

\section{Review of Literature}

Samuel and Sharma (2016) explained that technology plays a pivotal role enabling various societal functions but the terrorists possessed technologically advanced apparatus like Global Positioning System, online mapping tool, Google Earth to retrieve satellite images of the intended targets and this marked a significant shift in this contemporary era (p.28). He wrote that ISIS has tremendous presence on social media platforms e.g. Facebook, YouTube, Twitter, WhatsApp, Tumblr and Instagram (p. 29). The best example would be the Mumbai terrorist attack in 2008 which was an eye opener for the law enforcement agencies regarding the changing challenges to the security situation around the world. The United States has currently invested a huge amount of capital along with robust mobilization of intelligence and law enforcement to counter the terrorist networks. Along with this, the US military strategy is to strengthen the paramilitary force of Kurdish Regional Government in Iraq, which has been operating against ISIS. Irondelle and Cadier (2013) pointed out that terrorism has come to be the principle challenge to international security, elevated from domestic terrorism to international terrorism and reaching a global audience. Among the three broad approaches as suggested regarding counterterrorism, the first approach is based on policing and intelligence which is a commonly used method in Europe and reflects a conception of terrorism based on criminal analogy (p.9). The second approach requires long-term strategies and third strategy is through the lens of war analogy (use of force, pre-emptive strikes, etc.). They quoted key threats from migration and distinguished three areas where migration can impact on national and/or international security; state capacity and autonomy; the distribution of power among states; and the nature of violent conflict (p. 12). The danger of migration is that migratory flows have been exploited by organized crime networks to generate profits from the smuggling of human beings, as well as by terrorist networks to access target states (p. 13).

\section{Methodology}

This research has carried out applying descriptive research method. Secondary sources are referred while conducting the research paper. As regards to identify the modern security challenges and international trends to curb the contemporary security challenges, the researcher has moved out through the major security problems faced by states in internal security and the strategy as initiated along with major development to defeat the threats has taken. The state mechanisms and initiatives in curbing the contemporary security challenges has screened through the security measures (policy, planning, legal systems, security arrangements, cooperation among states in regional and global scenario and other practices in terms of discourse analysis) applied by law enforcement agencies. Based on this analysis, this paper draws conclusions of role and review of law enforcement agencies in contemporary era. 


\section{2 | Journal of APF Command and Staff College}

\section{Conceptual Clarification of Security}

The word security emanated from the Greek word se-cura, meaning 'to be in a state of no fear' (Kasali, 2011 , p. 19). Though security is a contested concept, scholars on security agree that security is 'freedom from threat' to the human life through any means. With the development of the human society over the years, the security concepts have been framed as conventional security, traditional security, nontraditional security, human security and collective security. Traditional security is also called the security of the nation from outside threat to the sovereign existence of any independent state, and advocates the supremacy of the state interest and security of the people that should be the core interest and the state has no other options for survival other than through military might. In conceptualizing internal security, the scholar Mijah (2007) described that internal security may be conceived as the freedom from or the absence of those tendencies which could attenuate internal cohesion and the corporate existence of the nation and its ability to maintain its vital institutions for the promotion of its core values and sociopolitical and economic objectives, as well as meet the legitimate aspirations of the people; and finally internal security also implies freedom from danger to life and property and the presence of a conducive environment for the people to pursue their legitimate interest within the society (Imobighe, 1990, p. 224). But traditionally, most writings of security scholars were bound with the concept of the national interest and sovereignty in the sphere of realpolitik in international relations and having policy of nations called national policy. The development of the human society has been the emerging source for the development of new theories and principles in security disciplines from realpolitik to the concept of global security as a whole.

\section{Paradigm Shift in Security}

A security paradigm can be understood as a conception of security situation in a particular society which has a particular trend. There is no doubt that security has been a subject that has attracted a rapidly growing interest and concern among the scholars in social sciences on a wide spectrum of issues on the subject and security has been studied and new breakthroughs and findings have been made. The experience of the world in recent times emphasizes a paradigm shift in security discourse (Kasali, 2011, p. 19). The notion of security paradigm has different roots like security situation of Middle East countries are different from West African states. The Westphalia notion of security was that the threat that came from the other state called the state-to-state aggression. During this notion, the major threat to the political sovereignty of any State usually emanated from another State (Kasali, 2011, p.19). After World War II, the concept of security has shifted to the individual person and groups, and responsibility has shifted to the state for protection and promotion. Subsequently, since the emergence of Cold War in 1945, the main challenge of state security has altered and new trend has found to internal security situation where most countries became plagued with insurgency and civil wars as experienced in every continent (Kasali, 2011, p. 20).

The end of the cold War in 1989 widened the scope of security studies due to the emergence of states without any defined political boundaries. The sharp increase in intra-state conflict in the developing world in the 1990's was a driving force for the re-evaluation of the relationship between development and conflict or insecurity (Smith 2001; Woods 2005; Swiss, 2011).The human security concept develops into wider scope and enlarges the horizon of security analysis from traditional security to the security of people. The interest and motives behind of some state and groups to the other state on political economy, power politics, resource; and influence of non-state actors in the domestic politics has also seen increasing. Due to these characteristics, the scope of security has been added ample of challenges to the state and people at large. For instance, the security environment of Southeast Asia has been challenged by the rapid economic changes, actual and potential disease epidemics, and a growing sense of shared interest and grievances among the region's Islamic populations are among the region's main transnational concerns (Ott, 2006).

\section{Modern Security Challenges}

The sources of threats have been changing day by day. This is the era of globalization with easy availability of information technology tools. While considering the modern security challenges, I relate the threats/challenges being faced by the modern states to the same problems as described by the ancient strategic philosopher Sun Tzu. He claimed that with the changing times, the threats have evolved and as he said, "we must force ourselves to ways of defeating a new enemy, one that is generally unseen, is 
driven ideologically, does not seek a set battle, and is like no other force before' (Rice, 2006). After the Cold War, the small states of South Asian countries have become the centre for external actors because of ideological collision among the states and lack of regional integrity. The proliferation of nuclear and small arms, Muslim fundamentalism, armed conflicts, secessionist tendencies and political transformation have rudiment in the world. And the emergence of brutal terrorist organization, ISIS, which practices new measures to attack and terrorize the people, has created a situation of vulnerability for the small and developing countries. Groups such as Al-Qaeda and Jemaah Islamiyah have been prepared to engage in symbolic crimes, directed at iconic social or cultural targets (e.g. the Pentagon), signal crimes (e.g. transport and nightclub bombings),intended to disrupt everyday life and perceptions of security, and spectacular crimes that combine the two types (Baral \& Shah, 2018, p. 5).

The suicidal tactic of using as a human bomb has become popular among the Jihadist Islamic groups, and such threats witnessed in European; South and West Asian countries, give the negative impression that security threats can be sponsored by certain groups and due to these techniques, now it has become difficult for security forces to identify and locate the terrorists. Thus, the human bomb is another complex challenge. The trend of suicidal attacks has increased dramatically. There were only a few attacks in the 1980 s and it rose slightly in the second half of the 1990's. However, it increased from 54 incidents in 2001 to 535 in 2007 (Atran, 2006; Moghadam, 2008; Irondelle \& Cadier, 2013). The recent trends of violence and attacks by the terrorists are such that the participation of such people at the spot itself is low but the degree of mass casualties leading to violence, hatred, threat and enmity is very high. At times, the attack may be relatively small in scale and harm, but the possibility that it was a trial run for a larger and more destructive attack in the future must be borne in mind as extremists have improved their explosive engineering skills (Noor, 2015, p. 7).In the past decades, EU has severely affected due to the growing instability and conflict in the neighbouring countries like Libya, Syria, and Sahel, Ukraine etc. The other problems such as economic and financial crisis in 2008, euro crisis in 2011-2-13, illegal immigration from the third countries, terrorist attacks and current threat of jihadist terrorist create the security situation of EU complex. The rate of suicide terrorism is also increasing in conflict prone countries like Iraq, Syria, Afghanistan and Libya.

\section{International Practices to Defeat the Contemporary Security Challenges}

The writings of contemporary security scholars have been characterized by the emphasis laid on equipping the security agencies with sophisticated weapons, arms and ammunitions, technology, intelligence gathering and training as per the growing internal threats to the society. Countries now emphasize newer approaches to security and aim for networked force structures that are both multi-usage and mobile (Gandhi, 2015). High policing was traditionally the function of security services using covert intelligence gathering directed at circumventing threats, while low policing was performed by public police, based on overt strategies of disruption of crime opportunities (Brodeur, 2007). The armed forces are divided into military forces, auxiliary forces and reserve forces. The rise of armed forces in the world is due to the threats and challenges that have been increasing with the changing global scenario. Of course, international security environment have a greater role in the domestic security situation of countries. Many contemporary security challenges - such as international terrorism and transnational organized crime - no longer neatly fit into one category, as they typically have both internal and external dimensions (Lutterbeck, 2013). The dynamics of security situation and its challenges to other countries within a short span of time, accompanied with the complexity of the threats enforced on the states have compelled countries to establish a strong armed security agency, referred to by different names in different countries like paramilitary force in India, gendarmerie force in Europe and Armed Police Force in Nepal. They have a role like that of the military but with a police identity. These security forces have the potential to curb the contemporary security situation and show their role by effective neutralization of threats.

In Australia, for example, successive new legislation from 2001 onwards has greatly expanded the size, role and functions of the Australian Federal Police (AFP - a national agency), given them broad new powers, and expanded and harmonized the counter-terrorist functions of the various state and territory police, responsible for most criminal law enforcement (Ransley \& Mazerolle, 2009; AFP, 2017). From this perception, the police agencies have been categorized on the basis of their functions to curtail security problems and their role and responsibilities have also been framed as per the level of threats that they need to tackle. Security policy experts note that the rise of non-state actors will dominate the future 


\section{4 | Journal of APF Command and Staff College}

global scene (Hauser, 2007). The perspective is that it is of paramount necessity to establish police forces with specific training to tackle the modern security challenges. This type of security agency has named as 'paramilitary', i.e. role of police and military. Auten defines 'paramilitary' as organized military, but not part of or in cooperation with the official armed forces of a country; having to do with military force in its tactics, or existing where there are no military services, or existing alongside the military services and professional non-military but formed on an underlying military pattern as a potential auxiliary or diversionary military organization (Auten, 1986, p. 68).

\section{US Department of Homeland Security}

For the United States, the 9/11 attacks led the country to declare a 'global war on terrorism', military intervention in Afghanistan to defeat the Taliban regime and destroy Al Qaeda's base, and in 2003 a preemptive war in Iraq. The most significant development after 9/11 was the reorganization of federal agencies under the umbrella of the US Department of Homeland Security (Ackleson \& Heyman, 2010). The 9/11 Commission had substantially faulted the lack of cooperation among government intelligence agencies (Eldridge et al., 2004; Warner, 2010).They indicated that the United States had not been prepared to counter a major terrorist attack because of lack of coordination of intelligence agencies and law enforcement (Warner, 2010, p.28). As per the Homeland Security Act, 2002, the United States formed the Homeland Security. At home, the US government undertook fundamental organizational reforms, including establishing a Department of Homeland Security and rearranging the nation's intelligence bureaucracy into a National Counterterrorist Centre. Armed Police and paramilitary organization patrol the US-Canada border, referred to as the "longest undefended border" in the world, but that changed dramatically after 9/11 (Winterdyk \& Sundberg, 2010, p. 27; Warner, 2010, p. 29).

\section{Canadian Border Services Agency (CBSA)}

The government of Canada introduced a number of measures to prevent and intercept "irregular migrants" from entering or remaining within its borders (Aiken, 2006). In a move parallel to the United States' creation of the Department of Homeland Security, Canada created the umbrella Canadian Border Services Agency (CBSA) to house the former customs, immigration, and food inspections services, and it became the first armed service to patrol (Warner, 2010).Canada has allocated resources to interdiction of "irregular migrants" to prevent or intercept the entrance of terrorism suspects (Aiken, 2006; Warner, 2010). Canada passed its Anti-Terrorism Act in 2001.The Anti-Terrorism Act is well sufficient to deter, prosecute, convict and punish the terrorists and terrorist groups those are acting in soil of Canada. In 2006, the Canadian government allocated \$101 million to arm 4,800 Border Services officers like ballistic vests and carry handguns to operate as a paramilitary organization (Warner, 2010). The CBSA is responsible for integrated border security in Canadian border. The CBSA works closely with international partners to identify best practices and guidelines and has adapted its own learning products to meet the specific needs of recipient administrations and this agency has internationally renowned centres of expertise that deliver training and provide mentoring expertise related to marine operations, border services officer recruitment, detector dog programs, and laboratory and forensic sciences (CBSA, 2014).

\section{European Union Context}

Prior to 2001, the European Union (EU) did not have a common definition of terrorism or penalties (Warner, 2010).Following 9/11, a debate has been continuously raising on state foreign and security policy. For the foreign policy of the EU, ' $9 / 11$ ' did not constitute a turning point in the first place [nor did the terrorist attacks in Madrid in March 2004 and in London in July 2005] (Biscop, 2008). Increasingly, even the strongest military powers in the EU, Britain and France accept that they cannot deal with global security problems on their own, but despite the strength of the argument for collective action, the EU has been able to act (Chappell, Mawdsley \& Petrov, 2016). In Europe, the EU raised terrorism to priority status as per its 2003 Security Strategy, called European Security Strategy (ESS), while it expanded counterterrorism policies and tightened counterterrorism links with the US (EU Council, 2003; Irondelle \& Cadier, 2013). Ten years earlier the European Security Strategy (ESS) claimed 'the post-Cold War environment is one of increasingly open borders in which internal and external aspects of security are indissolubly linked,' and where 'none of the new threats is purely military; nor can any be tackled by purely military means' (European Council, 2003, p. 2-7; Shepherd, 2016, p. 1). 
International, and especially transatlantic, police, counterterrorism and intelligence cooperation have since then developed to unprecedented levels (Irondelle \& Cadier, 2013). In 2008, terrorist activity in EU member states except for the United Kingdom decreased by 24 percent as compared to2007 (Europol, 2009; Warner, 2010). In 2008, 515 terrorist attacks were prevented before mission accomplishment and over 1,000 terrorist suspects were arrested in 13 EU states (Warner, 2010). Accordingly, the EUROPOL aims improving the effectiveness of the member states, and also has been working in gathering and sharing intelligence with member states.

While considering the development of gendarmerie force in EU, the evidence is seen in the considerable expansion of gendarmerie- type forces since the 1990s, as well as their increasingly important role in addressing many security challenges of the contemporary period, ranging from border control and counterterrorism to international peace operations (Lutterbeck, 2013). The internal security of France is the responsibility of two major police forces: the national police force, governed by a civil statute, which is under the supervision of the Ministry of Interior, and the national gendarmerie, which is the military police under the supervision of the Ministry of Defence (Vitkauskas, 1999). The European Gendarmerie Force in Italy also called Carbinneri having the nature of paramilitary force with military status, capacity to perform of security and justice and mitigating threats and risks in a complex environment of international terrorism, organized crime and crisis situations.

\section{Indian Paramilitary Forces}

In India, each state has its own police system. The central government is empowered by the constitution to raise and organize forces to protect the nation and to maintain its territory (Mishra, 2015). As of 1979, the paramilitary forces like Central Reserve Police Force (CRPF), Border Security Force (BSF), Central Industrial Security Force (CISF), Coast Guard, and Assam Rifles were existed. The CRPF was established by the colonial rule in situation of people's protest that the British Indian Army was not effective in controlling the freedom movement. Subsequently, CRPF was engaged in several operational activities to control the insurgency movement following important role played during the 1965 Rann Kutch conflict. After Rann Kutch, BSF was created for ensuring border security of India. The BSF has more modern and sophisticated weapons and its education and training are of a high level (Mishra, 2015, p. 374). The Coast Guard was established in 1976 under the control of the Ministry of Home Affairs to protect the territorial waters along its 3400 mile coastline.

Accordingly, the paramilitary security agencies like ITBP, BSF and Assam Rifles were established for the purpose of counter-terrorism, border guards, and to deal with other various security threats, riots and violence. ITBF was raised in 1962 to guard the India-China border along Tibet; BSF was created in 1965 to ensure the security of India-Pakistan border; NSG came into existence in 1986 as a specialized commando force to deal with specific threats posed by terrorist violence. The ITBP and SSB guard the Indo-Tibet and Indo-Nepal and Indo-Bhutan borders respectively; the CISF is engaged in providing security cover to all major airports, metro stations, and nuclear installations and about 200 PSUs across the country. The NSG today is a well-equipped and has two strikes and three support battalions suitably poised to rapidly respond to any internal security contingency ('Role of Paramilitary and Central Armed Police Forces in India's National Security', 2012). The terrorist attack on Hotel Taaj in Mumbai, in 2008, is a typical example of handling and controlling the situation by NSG, a specialized armed force.

\section{Paramilitary Force in Indonesia}

In Indonesia, a paramilitary unit with 12,000 personnel has been established as an elite corps unit with the mission of domestic security and defense operations (Dillon, 1997). Though, Indonesian National Police is the second largest police force after the army it is active in the security role as a regular police force of the country. Indonesia has a different style of security arrangement consisting of four agencies called the Armed Forces of the Republic of Indonesia (Angkatan Bersenjata Republik Indonesia, or ABRI) directly serving the nation through dual functions. ABRI consists of four services: The army, navy, air force, and police and among the services, the army has a dominant role (Dillon, 1997). The Indonesian National Counter Terrorism Agency instituted in 2010, is currently domestically active against terrorism.

\section{Armed Police Force, Nepal}

In changing trends of global security and increasing non-traditional threats, Nepal government established Armed Police Force, Nepal, popularly known as the APF in 2001 with motto "Peace, Security 


\section{6 | Journal of APF Command and Staff College}

and Commitment" and ethos "Any Task, Any Time, Any Place". Though the establishment of the organization was at the period of Maoist insurgency, the government of Nepal has deployed APF with multiple tasks and responsibilities. Previously, Nepal Police along with National Investigation Department were performed as law enforcement agencies and engaged in internal security of Nepal. APF has established to neutralize contemporary security challenges like terrorism, insurgency, transborder crime and riots along with other security challenges. Currently in Nepal, the Armed Police Force Nepal has been tasked with thirteen mandates regarding the internal security of Nepal. The roles like border security, counter insurgency, controlling armed violence, and separatist movements, riot control, VIP/VVIP security and industrial security are core mandates of Armed Police Force Nepal. Accordingly, now in APF, about thirty seven thousand troops having effective and efficient capacity in Disaster Management, Industrial Security of Nepal, Revenue and Custom Security are performing well.

\section{Intelligence Agencies in Internal Security}

The design of security operation depends on intelligence. The utilization of Intelligence is common in internal security of any state. The intelligence agencies have become a compulsory for the state security. Within the framework of complex and volatile environment of non-traditional security, states have been deploying intelligence for the internal security. The practices of intelligence collection of many countries include overt and clandestine methods. The DST (la Direction de la Surveillance du Territoire) is responsible for domestic security intelligence in France (Vitkauskas, 1999, p. 7). The main function of the DST is to collect information that includes foreign intelligence. The DST is part of a wider national police structure and DST Director maintains close relations with the Director General of the National Police (Vitkauskas, 1999). In Germany, the Federal Office for the Protection of the Constitution or the FOPC, functions as a domestic civil security intelligence service; the British Security Service, the socalled MI5, is responsible for domestic security intelligence in the United Kingdom but British Secret Intelligence Service (SIS, also known as the MI6) conducts foreign intelligence; domestic security intelligence in the US is collected by the Federal Bureau of Investigation (FBI) and Central Intelligence Agency (CIA) for foreign intelligence (Vitkauskas, 1999, p. 7). The location tracking and all necessary information for the special force (marine commando) in Bin Laden operation can be taken as a good example of intelligence role in national security.

\section{Findings}

Unless the roots of the security threats are identified, it can generate unprecedented dilemma for the security agencies to curb such threats. However, new opportunities for the law enforcement agencies are generating better ways to address or overcome those challenges in a more effective and efficient manner. Most of the countries across the world have established armed forces to defeat the contemporary security challenges. The nature of policing is more to engage in crime control and democratic policing. Due to the nature of modern security threats, it has become more complex to control only through regular policing. The rise of law enforcement agencies like APF has been more effective in curbing the contemporary security challenges. Thus, the international trends are being empowered armed police, paramilitary and auxiliary type law enforcement agencies with relevant training programs, weapons and logistics so that they can better contribute to the internal security of the nation. Similarly, the state's intelligence agencies are being equally enhanced even more to collect security information to counter threats. Their role consists of active participation for collecting information regarding the various security issues that directly and indirectly pose threats to the internal and external security of the nation. According to Hans J. Morgenthau, 'armed strength as a threat or a potentiality is the most important material factor making for the political power of a nation' (Troxell, 2008, p. 209).Clearly, it is seen that the international practices to deal with contemporary security challenges have been shifted to the auxiliary or paramilitary security agencies that has the capacity to perform actions like regular army due to the complex security environment. Likewise, the Intelligence related agencies can also perform in internal security with a bird's eye view against anti-national and anti-social activities.

\section{Conclusion}

Contemporary security is vulnerable due to the negative implications of globalization, interdependency of states, transnational activities of criminals and armed groups, sectarian politics, influence of domestic issues by non-state actors, and global terrorism. Presently, the lives of people are highly threatened due to these nonconventional types' security threats. Due to the geography and location of some sates, it is 
found that they are more susceptible to contemporary security threats than others. Hence, to fight against these security challenges, the law enforcement agencies should be able to perform effectively. In this $21 \mathrm{st}$ century, the law enforcement agencies, particularly, armed police types law enforcement agencies having military nature are more effective to curb the contemporary security challenges. Accordingly, intelligence agencies are also carrying out to support the other law enforcement agencies in security related operations and activities.

After the 9/11 terrorist attack in US, the government has established new law enforcement agency, Department of Homeland Security that has the capacity to tackle the security challenges. Similarly, Canada and EU has also established and reformed the law enforcement agencies and introduced new security measures to control the new threats. Similarly, different countries have introduced new plans in internal security. Most of the countries border security is generally concentrated for the prevention of terrorism, extremism, transborder crime and other security threats that pose serious threat to the national security of the nation. The internal security is the responsibility of all security agencies of the state. The internal security would be strong if the state security mechanisms are bonding collectively to tackle the challenges. However, the international practices to defeat the contemporary security challenges could be a lesson learnt for the law enforcement agencies in present context. Ultimately, long-term security, peace and stability will depend on the security policy of the nation, so a comprehensive security policy should be indigent that reflects safety and security, rule of law, respect of human rights and fundamental freedoms of the people.

\section{References}

Ackleson, J. \& Heyman, J. (2010). United States border security after 9/11.In border security in the Al-Qaeda Era, John A. Winterdyk\& Kelly W. Sundberg (ed.), 37-76, New York: CRC Press.

AFP.(2017).Policing for a safer Australia: strategy for future capability. Retrieved from https://www.afp.gov.au/sites/default/files/PDF/strategy-for-future-capability.pdf

Aiken, S. (2006). Interdiction and the post 9/11 security agenda: A Canadian perspective. Retrieved fromhttp://www.cerium.ca /article1932.html

Atran, S. (2006). The moral logic and growth of suicide terrorism.The Washington Quarterly, 29(2), 127-147.

Auten, J. (1986). The para military well of police and police professionalism.Police Studies.

Baral, U.M.\& Shah, A. (2018).National security of Nepal: threats, challenges and solutions.International Journal of Humanities and Social Sciences, 1(1). Retrieved from http://www.crossingtheborder.com.np/epaper/vol1_ijhss/1.pdf

Biscop, S. (2008). The EU and the European security strategy: forging a global Europe. In Biscop, S \&Andersson, J. J (ed.), London and New York: Routledge.

Brodeur, J.P. (2007). High and low policing in post-9/11 times.Policing, 1(1), 25-37.

CBSA. (2010). Canada Border Services Agency: International capacity building program. Retrieved from https://www.cbsa-asfc.gc.ca/publications/pub/bsf5134-eng.pdf

Chappell, L ., Mawdsley, J., \&Petrov, P. (2016). The EU, Strategy and Security Policy: Regional and Strategic Challenges. Routledge Studies in European Security and Strategy, Routledge.

Dillon, R.D. (1997). Contemporary security challenges of South Asia.Parameters Spring,193-31. Retrieved from https://ssi.armywarcollege.edu/pubs/parameters/articles/97spring/dillon.htm

Dokubo, C. (2010).The Proliferation of Small Arms and Light Weapons in West Africa: Implications for sub regional Security. In Eze, O., Anigbo, C., and Dokunbo, C. (eds.), Lagos: Nigeria Institute of International Affairs.

Eldridge, et. al. (2004).9/11 and terrorist travel. Staff report of the National Commission on terrorist Attacks upon the United States. Retrieved from https://govinfo.library.unt.edu/911/staff_statements/911_TerrTrav_Monograph.pdf.

EU Council. (2003). A Secure Europe in a better world.European Security Strategy. Brussels.

Europol. (2009). TE-SAT 2009: EU Terrorism Situation and Trend Report. Retrieved from http://www.scribd.com/doc/14818199/EuroPol-2009-report.

Gandhi, P. (2015). The emergence of the Asian defense industry: Are China and Japan going to face a war in 'Business of War'.Retrieved from https://www.academia.edu/12894581/The_Emergence_of_the_Asian_Defence_Industry_Are_China_ and_Japan_going_to_face_a_War_in_Business_of_War_ 


\section{8 | Journal of APF Command and Staff College}

Hauser, G. (2007). Austrian Security Policy - new tasks and challenges. Obrana A Strategie. Retrieved fromhttps://www.obranaastrategie.cz/cs/aktualni-cislo-1-2007/clanky/Austrian-security-policy-newtasks-and-challenges.html

Imobighe, T. A. (1990). Doctrines for and threats to internal security.Lagos: Malthouse.

Iregbenu, P \&Uzonwanne, C. (2015).Security challenges and implications to national stability.Journal of Economics and Sustainable Development, 6(4), 196-175.

Irondelle, B. \& Cadier, D. (2013). Evolving threats and new security domains.Transworld.

Kaljurand, R. (2012). Security challenges of a small states: The case of Estonia. Centre for Small State Studies Institute of International Affairs.

Kasali, M. A. (2011). Basic Security and Security Threats.National Open University of Nigeria.

Lutterbeck, D. (2013). The paradox of Gendarmeries: Between expansion, demilitarization and dissolution.Ubiquity Press.

Manwaring, G.M. (2011). The strategic logic of the contemporary security dilemma.Strategic Studies Institute Monograph, US Army War College.

Mijah, E. B. (2007). Democracy, internal security and the challenges of policing in Nigeria. Nigeria Defence Academy: Kaduna. Retrieved from http://www.loccum.de/material/interpol/nigeria/mijah.pdf

Mishra, K.P. (2015). Paramilitary forces in India.Jawaharlal Nehru University.

Moghadam, A. (2008). The globalization of martydom: Al Qaeda, salafi jihad and the diffusion of suicide attacks.Baltimore: John Hopkins University Press.

Ngwube, A. (2013). Threats to security in Nigeria. Review of Public Administration and Management, 2(3), 262-278. Retrieved from https://www.arabianjbmr.com/pdfs/RPAM_VOL_2_3/24.pdf

Noor, E. (2015). Security challenges for Malaysia: Defending the nation state. Retrieved fromhttp://www.nids.mod.go.jp/english/publication/joint_research/series15/pdf/chapter04.pdf

Ott, C.M. (2006). Southeast Asian security challenges: America's response? Strategic Forum. Institute for National Strategic Studies: National Defense University. Retrieved from https://www.files.ethz.ch/isn/46275/SF222.pdf

Ransley, J, \& Mazerolle, L. (2006). Third party policing.Cambridge University Press.

Rice, S. (2006). Sun Tzu: Ancient theories for a strategy against Islamic extremism. U.S Army War College.

"Role of paramilitary and Central Armed Police Forces in India's national security", (2012).CLAWS. Retrieved from http://www.claws.in/images/events/pdf/ 336760641_Report Role of PMFCAPF NAtionalSecurity.pdf

Samuel, C \& Sharma, M. (2016).Securing cyberspace: International and Asian perspectives.Institute for Defense Studies and Analyses. New Delhi.

Shepherd, A. J. (2016). CSDP and the internal- external security nexus, the EU strategy and security policy: Regional and strategic challenges. In Chappell, L, M. \&Petrov, P. (ed.), Routledge Studies in European Security and Strategy, 87-226.

Smith, A.F. (2006). Intelligence transformation: Using threat characteristics to define division capabilities. Kansas: School of Advanced Military Studies.

Swiss, L. (2011). Security sector reform and development assistance: Explaining the diffusion of policy priorities. Qual Social, 34 (2), 371-393.

Swiss, L. (2011). The adoption of women and gender as development assistance priorities: An event history analysis of world polity effects. International Sociology.

Troxell, F. J. (2008). Military power and the use of force.Theory of War and Strategy, 1(1), US Army War College.

Vitkauskas, D. (1999). The role of security intelligence service in a democracy.Democratic Institutions Fellowships Programme 1997-1999.Retrieved from https://www.na to.int/acad/fellow/ 9799/vitkauskas.pdf

Warner, J. A. (2010). US border security: A reference handbook. Contemporary World Issues Series, California: Santa Barbara, Colorado: Denver \& England: Oxford.

Winterdyk, J. A. \&Sundberg, K.W. (2010). Introduction. In Winterdyk, J. \&Sundberg, K.W (ed.),In Border Security in the Al-Qaeda Era,New York: CRC Press.

Woods, N. (2005). The shifting politics of foreign aid. International Affairs, 81(2), 393-409. 